\title{
The politics of international migratory regimes: transit migration flows in Turkey
}

\author{
Ahmet Içduygu
}

\section{Introduction: international migratory regimes (IMRs)}

Among the features distinguishing the demography of the modern world from its predecessors are the types and patterns of international migration. For instance, international migratory flows directed to the European countries tend to include a significant proportion of migrants who first come to the peripheral zones of Europe, such as Eastern Europe, Western Asia, or Northern Africa, intending to enter Europe from those areas. The changing character of human mobility from developing countries to Europe has profound consequences for the politics of international migration and for the distribution of power between countries touched by various forms of migrations.

It is within this context that the high level of transit migration flows around Europe in the last two decades has been one of the most hotly debated items on national and international agendas. For instance in the early 1990s, when it was found that many migrants from Asia, Africa, the Middle East and the Commonwealth of Independent States (CIS) passed through peripheral zones on their way to Western Europe, the International Organization for Migration (IOM) decided to focus the first efforts of its Migration Information Programme on analysing this issue.
The result is a series of reports on transit migration in several countries such as Bulgaria, the Czech Republic, Hungary, Poland, Russia, Ukraine, and Turkey. ${ }^{1}$ In the second half of the 1990s, the issue of transit migration around Europe was debated in several international meetings, ${ }^{2}$ and immigration debates in Europe still reflect the importance of the issue.

This article explores the ways in which transit migration flows are associated with the politics of international migration. It takes a careful look at the politics of international migratory regimes (IMRs), interpreting the word 'regime' very loosely to mean a regulatory system which operates in certain interests and distributes powers and advantages or disadvantages. It argues that the globalisation of human mobility has helped to extend international migratory movements in a form of international regulatory system. It also argues that recent patterns of change in human mobility are outcomes of quite complex interactions, with simultaneous and sequential operation of a variety of interacting factors. These include characteristics of the migrants themselves, of the society they enter, and of the society they leave. Looking at transit migration flows and their associations with IMRs opens a number of questions about the relationship between migration movements and the socio-political background, since IMRs are 
essentially political outcomes or compromises which both reflect and shape global mobility change.

The case study for the present analysis is Turkey, a particularly appropriate country for such inquiry because of its long established attachment to the European IMRs. It should be noted that not all aspects of transit migration are analysed here. For our present purposes, some basic characteristics of transit movements suffice to define an international migratory regime. While referring to the dynamics and mechanisms of transit migration in Turkey, we focus on four main dimensions that describe an international migratory regime: level and pattern over time, origins of flows, places of destination, and characteristics of migrants.

\section{Background}

Turkey has been a main actor in international transit migratory movements for the last two decades (Gokdere 1994, 49; Içduygu 1996a, 128; IOM 1995, 1). Thousands of migrants, with the intention to stay temporarily, have come there from countries as diverse as Iraq, Egypt, Morocco, Ghana, and Afghanistan, often to find their way to the developed countries in the west and north. There are three factors that seem to be shaping these migratory movements to Turkey. First, the ongoing political turmoil and clashes occurring in neighbouring areas have pushed people from their homelands in the hope of a better life, security and protection from persecution. Second, Turkey's geographical location between East and West, and South and North, has made the country a suitable transit zone for those intending to reach western and northern countries. Third, the policies of 'Fortress Europe', applying very restrictive admission procedures and increasing immigration controls, have diverted immigration flows targeting Europe to peripheral zones around it, like Turkey.

Since the early 1960s the relationship of Western European countries with Turkey has been intertwined with the high profile of migration. The labour migration of the 1960s and $1970 \mathrm{~s}$ and the family reunification of the 1980 s led to the formation of an established migration regime between Europe and Turkey.
In the 1990s it has been dominated by the transit migration and asylum issues (Kirisci 1994, ZFT 1996). Again in the 1990s the European Union took the lead in the formulation of a new migration and asylum regime. The asylum regime has changed from a liberal one implementing a selective but integrative policy of access and full status recognition, with complete social rights and long-term settlement, to one maximising exclusion on entry, undermining status and rights, and with the perspective of a short stay (Joly 1998).

A 'comprehensive' approach prioritises action outside EU reception countries to provide help in situ, and to settle potential asylum seekers in countries as close as possible to the region of origin. This is implemented through readmission agreements and 'safe third country' resolutions (Joly 1996). The process is likely to have a strong impact on migration from, to and through Turkey (Içduygu 1995).

The immigration and refugee crisis dominating the agendas of Europe and Turkey since the early 1990s continues as a hot debate on what should be done with transit migrants and refugees. With this background, this essay investigates transit migration and refugee flows in Turkey, evaluates the wider context of the formulation of migration, asylum and refugee regimes between Turkey and Europe, and relates the issue of transit migration to the ongoing dynamics of globalisation.

There is a widely accepted typology of international migration which consists of six main types of migrants (Appleyard 1991, 1995): (1) permanent settlers, (2) temporary contract workers, (3) temporary professional employees, (4) clandestine or illegal workers, (5) asylum seekers, and (6) refugees. To this typology, another category may be added, these are the transit migrants, who are the people who come to a country of destination with the intention of going to and staying in another country. From the beginning it is necessary to remind ourselves that although the transit migrants are usually associated with specific migratory context, they often occur within a web of other types of migration. For instance, clandestine or illegal workers, asylum seekers, refugees and transit migrants often overlap. In other words, the category of transit migrants consists of a mixture of various types of migrants. Therefore, 
the concept of transit migration must be constructed according to a typology which recognises not only the intention of migrants but also the dynamics and mechanisms of the whole migration process.

While a great deal of research attention has been paid to various types of international migration, there has been very little consistent research done on the issue of transit migration in an international context (Içduygu 1996a, IOM, UNHCR, and OSCE 1996). Study of the various types of migration could, of course, yield leads and insights about transit migration, but the types of international migratory movements are hardly the same. It is obvious that we need to know more than we do about the transit migratory movement, which involves particular structures and processes. We also need to know about the social, economic, and political characteristics of the sending, hosting, and receiving countries involved.

From a theoretical perspective, three points should be made. First, it is important to the understanding of the migratory process in its totality, including the links between the various stages of the transit migratory process, such as pre-migratory background, physical transition, and resettlement. Second, one should look at migration from a historical perspective. Third, one needs to locate and conceptualise the position of individual migrants within the totality.

In the vast and diverse literature on international migration and migrants, theoretical and empirical studies can be grouped into four major research areas: the origins of migratory flow, the determinants of their stability over time, the uses of migrant labour, and the adaptation of migrants into the receiving society (Portes and Bach 1985, 3; Portes and Borocz 1985, 606). Generally speaking, the causes of migration are at the centre of attention in the first two areas, while the focus is on consequences in the following two areas (Morokvasic 1984, 17). The subject on transit migration brings together causes and consequences. Their close interaction is revealed by the role of the transit migrants themselves. They are not merely subjects whose moves are determined by structural factors. They are also actors who formulate their own strategies and life projects in their societies of origin and reception, which they in turn modify (Joly 1998).
It is widely argued that contemporary migratory flows contribute to changing meanings of concepts such as nation, state, nationstate, citizenship, multiculturalism, residence, nationality, community, identity and social relationships resulting from globalisation (Içduygu 1996b, 150). Today, the migration regimes of nation-states, which were to a large extent framed by the state-centric logic of the Cold War, are becoming problematic and ineffective, as migration flows are becoming manylayered and not easily controlled by individual states. Consequently, migration flows are often seen as a potential security threat, and figure largely in discourse on national and international security (Içduygu and Keyman 1998, Kirisci 1994).

Turkey provides an illustrative case, where the nation-state lacks an effective migration policy, and is very much affected by the immigration and asylum policies and practices of European countries. Turkey also constitutes an ideal case-study, because of both its high rate of emigration and its experience of refugee flows and transit migration (Içduygu and Keyman 1998).

\section{Transit migration in Turkey ${ }^{3}$}

Official statistics, based on data compiled by the State Institute of Statistics in Turkey, show that over the last 20 years (1979 to 1999) more than 55 million foreigners arrived in Turkey. Most of these arrivals were tourists who were travelling for recreation, holiday, family visit, business and similar purposes, but some were persons intending to settle in Turkey temporarily or permanently. There were also transit people who came with the intention of going to and staying in a third country. There is no reliable categorisation of arrivals in the official statistics, nor a clear indication of the levels of the different types of migratory flow. However, it is clear that since the early 1980s there has been a sharp increase in the movement of foreigners into Turkey.

Slightly more than a quarter of the 55 million foreigners who entered the country between 1979 and 1999, did so in the first ten years of that period. The remaining three-quarters arrived in the second decade. In other 
words, the number of foreigners arriving in Turkey was tripled in the period of 1989-1999. Besides the increasing numbers of the arrivals in the context of tourism, possibly there was an intensifying movement of people who desire to settle in Turkey or who want go from Turkey to a third country.

To better understand the transit phenomenon in Turkey, it is necessary to refer to recent refugee flows into the country. ${ }^{4}$ The movement of refugees is not the same as that of other transients, but information on the former may cast light on the latter. Although Turkey was one of the signatories of the 1951 Geneva Convention, it accepted the Convention with a geographic limitation: its obligations would be applied only to persons seeking asylum from Europe, without obligation with regard to nonEuropean refugees. Given the anti-Communist policy of the country during the Cold War period, this meant that Turkey granted refugee status only to people coming from Eastern Europe and the former Soviet Union. Also given the strong commitment of the West to resettle those fleeing communist persecution, Turkey also expected to serve only as a transit country for the refugees.

Until recently the number of asylum seekers and refugees into Turkey was very small and sporadic, restricted to Eastern European cases; and those who were accepted as refugees were usually encouraged to resettle in the Western countries. According to UNCHR statistics, there were less than 8,000 asylum seekers coming to Turkey from Eastern Europe and the Soviet Union in the period 1945-1991, nearly half of them arriving in the years from 19791991. There was no clear indication what proportion of these asylum seekers was actually accepted as refugees, but it is highly likely that vast majority of them left Turkey for a third country.

Since the 1980s, Turkey has found itself in a situation where thousands of asylum seekers, mostly from the Middle East but partly from some distant parts of Asia and Africa, are entering the country. Having no special regulations regarding the status of non-European asylum seekers, Turkey has responded in using its general laws on foreigners coming into the country. Accordingly, Turkey has expected that incoming foreigners must possess a valid docu- ment, and must leave the country within the permitted period of stay. At the same time, on the basis of various de facto refugee developments, the Turkish authorities, applying a certain degree of pragmatism and flexibility, have enabled asylum seekers to enjoy some form of protection. Within this context, large number of Iranians escaping from the Khomeini's regime have been able to enter and stay in Turkey without an appropriate travel document and residence permit.

The first mass arrivals of non-Convention categories of refugees to Turkey, who might also be considered as transients, were Iranians. After the Islamic Revolution of 1979, thousands of Iranians, some arriving with valid documents but others without, sought refuge in Turkey, but the majority had the intention of using Turkey as a transit area to pass to Western countries. Under current regulations in Turkey, these Iranians have not been recognised as asylum seekers in the sense of the Geneva Convention, and have been allowed to stay on as tourists for time periods that are regularly extended.

Only a small proportion of Iranians have chosen to use the channels of the UNHCR to resettle in a third country, while the majority have tended to find ways to the West using their own connections. There is no direct evidence on the actual number of Iranians who have entered Turkey, but it is widely pronounced that almost one million Iranians have used the country as a transit. It is estimated that a residual one or two hundred thousand are still in Turkey.

Turkey's second largest flow of transit migrants was made up of three mass arrivals from Iraq between the years 1988 and 1991. The first came in 1988 when the Iran-Iraq War ended. Pushed by Iraqi military actions more than 50,000 Kurdish peshmergas (guerrillas) and their family members poured into Turkey in the last week of August 1988. It was again because of Turkey's geographical limitation in the Geneva Convention that the arriving people from Iraq were considered as 'temporary guests' rather than asylum seekers, and were expected to leave Turkey as soon as possible. Since Turkey was against the idea of granting refugee status to these Iraqi Kurds, the UNHCR was not allowed to approach them to give assistance and protection. The peshmergas and their families were housed in temporary shelter centres 


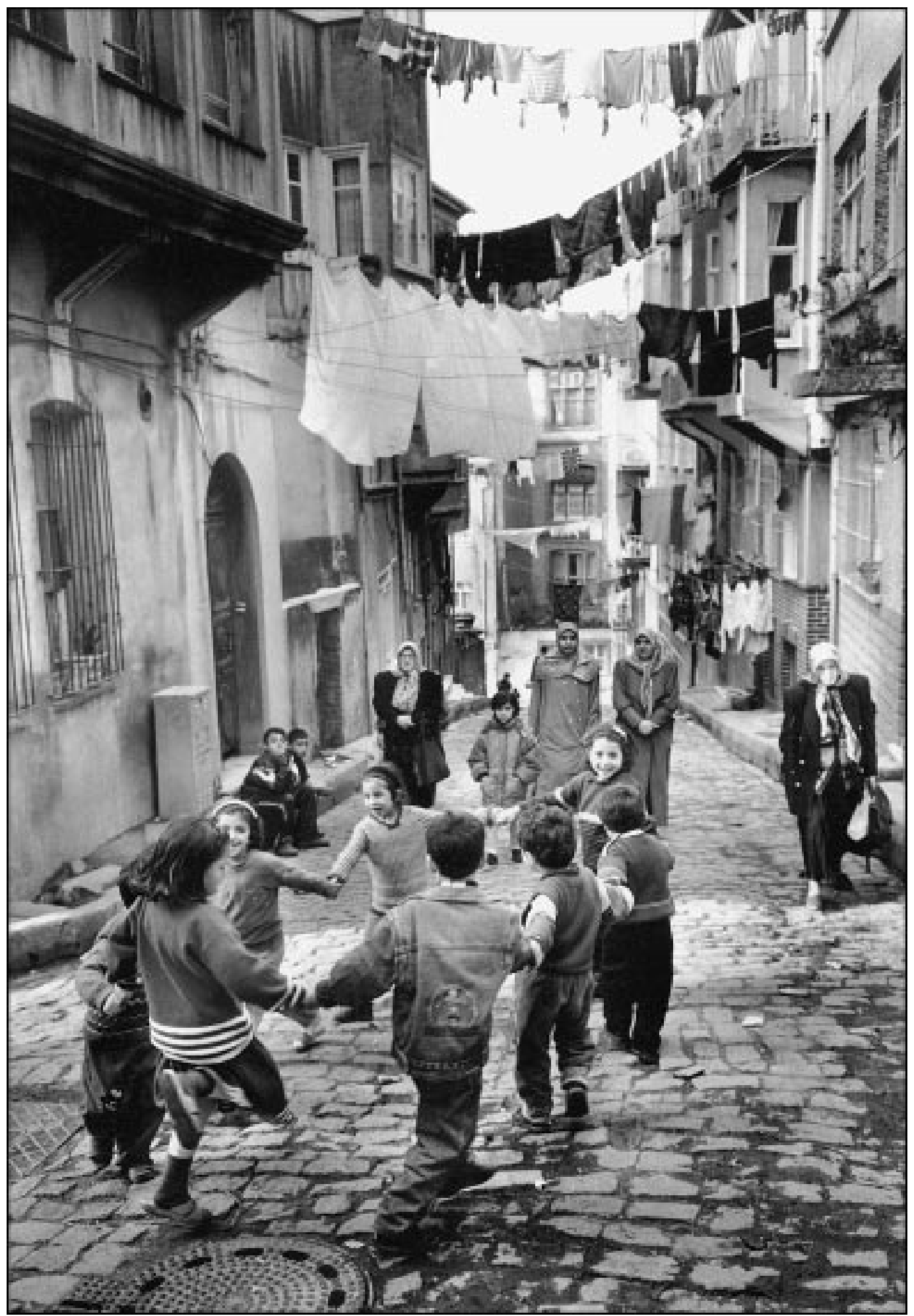

Street scene from the old quarter of Istanbul, 1996. Antoine Agoudjian / Rapho 
close to the Iraqi border, and encouraged to go home or seek refuge in the West rather than to stay in Turkey. In fact, a survey showed that 26,873 among 27,028 interviewed Iraqi Kurds living in the shelter centres intended to resettle in the West (Kirisci 1994, 52). However, Western countries were reluctant to accept them and wanted to keep the refugees in Turkey. At the same time, Western officials were quite critical about Turkey's treatment of these refugees, referring particularly to the quantity and quality of housing facilities and humanitarian assistance provided. On the other hand, when the West showed reluctance to accept any refugees for resettlement, the Turkish government was critical of the lack of Western interest in sharing responsibilities towards refugees.

Due to this conflict between the Turkish authorities and the West, only a few asylumseeking Kurds left Turkey from 1988 to early 1991. As from April 1991, however, a large proportion of the people from the 1988 influx joined their compatriots who had fled to Turkey in the mass exodus of early April 1991, and returned to the safe zone in the Northern Iraq. The voluntary repatriation of 1988 arrivals continued until recently. At the same time, nearly 2,500 of the total 50,000 left Turkey for Iran and Syria, and only around 3,000 were accepted as refugees, and resettled in the West.

The second flow from Iraq consisted of foreign workers in Iraq or Kuwait wanting to escape from those countries during the Gulf Crisis. Nearly 60,000 foreign workers and their dependants, mostly from developing countries in Asia, fled to Turkey across the Iraq border in the period between August 1990 and April 1991. These people were temporarily housed at a camp close to Iraq-Turkish border, and they left Turkey soon after their arrival when the necessary transportation arrangements were made by their national governments or international agencies.

The last mass flow of people from Iraq to Turkey occurred when half a million Kurds, running away from the Iraqi military, poured into the mountainous region separating Turkey from Iraq in early April 1991. After the difficult experience of the 1988 influx, Turkey was keen not to open her border to this mass flow, but it was difficult to control. However, compared with the 1988 experience, the international com- munity responded rapidly. Firstly, drawing the attention of the developed world to the huge dimension of the movement, Turkey pushed the West for a massive international humanitarian programme to meet the food and shelter needs of the arriving people. Secondly, advocating the idea of creating a safe zone in Northern Iraq, Turkey initiated a voluntary and safe repatriation programme. Consequently, half a million Kurdish refugees were brought down from mountain tops in Turkey to the plains on the Iraqi side of the border.

Despite the fact that a large proportion of arrivals from Iraq left Turkey, these mass Iraqi flows not only left a residual population in Turkey but also led to further immigration from Iraq into Turkey. Although the movement was mainly Kurdish, there were many Arabs, Chaldeans, and Turcomans also entering Turkey. For instance, in the period between the late 1980s and early 1991 there were almost 8,000 Iraqi asylum seekers who were mainly Arabs, Chaldeans, and Turcomans. Among these 8,000, almost half found their way to the West and resettled there, while the other half stayed in Turkey with residence permits.

In addition to other incoming migratory flows, 1989 was characterised by the movement of more than 310,000 Bulgarian Turkish asylum seekers fleeing the repressive regime of Bulgaria. Later, more than half of these refugees returned to their homeland. Only a very small proportion of them managed to go to other third countries.

Apart from the Middle Eastern flows from Iran and Iraq, there was a significant movement of asylum-seekers and other transit migrants from Africa and Asia to Turkey. Although there are no complete and reliable figures on the volume of this movement, it is recorded that from 1983 to 1991 there were 380 asylum seekers from African countries such as Ethiopia, Ghana, Nigeria, Somalia and Sudan; and 940 from Asian countries such as Afghanistan, China and Sri Lanka. It can be argued however that the total number of asylum-seekers from Asia and Africa is significantly higher than these figures suggest. A large proportion of the arrivals from Asia and Africa were undocumented migrants who entered Turkey illegally and wished to leave it illegally. It is estimated that in the mid-1990s there were respectively 
2,000 and 750 transit migrants from Africa and Asia in Turkey. In the late 1990s, the figures were more than 5,000 for Africans and over 1,000 for Asians. Overall, since the late 1980s, more than 30,000 transit migrants have arrived from African and Asian countries such as Ghana, Nigeria, Tanzania, Ethiopia, Sudan, Afghanistan, the Philippines, and Sri Lanka.

One of the more recent groups of transit migrants to Turkey came from Bosnia. The first flow of Bosnian refugees began to arrive in late 1992. While some of these people held former Yugoslav passports and entered as tourists, most of them entered without any documents. The vast majority of the Bosnian Muslims who came to Turkey stayed with relatives and other Turkish citizens of Bosnian ethnic descent, and a significant proportion of them intended to resettle in the West. Although there are no exact figures on how many Bosnians came to Turkey, some reliable sources put the figure as 20,000 to 25,000 . While more than three-quarters of Bosnians returned to their homeland, only a small proportion, nearly 2,000, stayed with relatives and friends in Turkey. Many Bosnians who came to Turkey with the intention of migrating to the West obtained refugee status in Western countries - the estimated figure is around 5,000.

The most recent group of transit migrants to Turkey was made up of Albanian refugees from Kosovo. Approximately 20,000 Albanians sought refuge in Turkey in 1999. The majority of these were considering it as a country of temporary asylum. Indeed, later a vast majority of them left Turkey for their homes, only about 1,000 are still living in Turkey.

Finally, here one should mention the movement of trader-tourists from the former Soviet Bloc countries. Although they can not be considered as transit migrants, they often become an integral part of the transit flows as they move in and out of the countries surrounding Turkey. The number of people in this category increased significantly in the 1990s. In this decade, the total number of visitors from these countries, the majority of whom were tradertourists, rose dramatically: from less than 600,000 in 1989 to nearly 3,000,000 in 1999.

\section{Transit migrants in Turkey ${ }^{5}$}

The 1995 study of Transit Migration in Turkey (IOM 1995) contains the results of detailed and systematic interviews with 159 men and women transit migrants in the two major metropolitan areas, Istanbul and Ankara. These areas were chosen mainly because they are representative of major transit migratory flows both into and out of Turkey. We summarise the major findings of these interviews.

In 1995 almost three-quarters of the interviewed transit migrants were male. Nearly $70 \%$ of them were aged between 17 and 30, and only $10 \%$ of them were more than 40 years of age. Three in every five were single. Seventy per cent were city-born people, and $67 \%$ were with at least a secondary level of education. A large proportion of the transit migrants $(67 \%)$ were either full-time employed or students, but with a high dissatisfaction related to their jobs or prospective job opportunities. Almost half of the sampled migrants indicated that they had blue-collar jobs in their homeland, and twothirds saw their income in the homeland as average. These results confirm that migration is selective mostly for young, urban-originated and educated males with less professional, social and economic satisfaction. Transit migrants have tended to migrate as individuals, even if they are married. The collected data indicated that only a quarter of them planned or attempted to bring relatives to Turkey.

The majority of the transit migrants were from the Middle East. More than one-third were Iraqi and one-fifth were Iranian. Transit migrants from Africa constitute another onefifth of the respondents while those from Bosnia were $10 \%$, and those from Asia were only $6 \%$. Ethnic Turks, of which the majority were Turcomans coming from Iraq, constitute one-fifth of the sample, while another one-fifth were of various African origins. The third major ethnic group of migrants were Persians who form 14\% of the sample. Ethnic Kurds, Arabs and Bosnians were represented by $9 \%$ each.

More than a half of the migrants referred to the 'political push' factors that brought them to Turkey. The push factors most often mentioned were armed conflict, ethnic intolerance, religious fundamentalism, and political tension. Economic motives, cited by over one-third of 
the respondents, were also of primary significance. Interviewed transients from Iran, Iraq and Bosnia often stressed the political reasons for migrating, while Africans and other Asians gave mainly economically oriented concerns.

Less than $60 \%$ of these transit migrants had been in Turkey for less than one year, while more than $10 \%$ were in the country for more than four years. The mean duration of residence for Iranians was almost four years, whereas for Iraqis, Bosnians and Africans they were 26, 21 and 13 months respectively. At the time of the interview, only $8 \%$ of the respondents wanted to stay in Turkey. Seventy-one per cent had previously attempted to leave Turkey, but were not successful in their efforts; and $92 \%$ were still planning to do so. The survey data indicate that transit migration is a very long process. The migration process from homeland to final destination through Turkey seems to take four years on the average: the average migrant said that he/she planned their move to Turkey for about a year, had been living in Turkey for almost two years, and was planning to leave for the country of final destination in another year.

Transit migration is very costly too. The total cost of migration is calculated as the cost of travelling from homeland to Turkey plus the cost of travelling from Turkey to the final destination. The estimated total cost of transit migration through Turkey was US\$3,700. A large portion of this amount was for bribing. For instance, in order to pass to Turkey nearly $50 \%$ of the respondents had to pay bribes at their homeland or at the border of a country neighbouring Turkey; and the average bribe paid before entering Turkey was US\$430, with a maximum US\$3,000 and a minimum of US\$5. Thirty-seven per cent had to pay bribes in Turkey and the average bribe paid on the Turkish side of border was US\$270, again with a maximum US\$3,000 and a minimum of US\$5. Twenty-five per cent of the respondents were planning to pay an average bribe of US\$2,400 in Turkey and $12 \%$ were planning to pay an average bribe of US $\$ 4,500$ at their final destinations. The range of expected bribery for the travel between Turkey and the final destination was wide from US\$100 to US\$10,000. The total cost of migration varies for various nationalities following different migration routes. For instance, the cost was much lower for Africans (US\$1,950) most of whom travelled hiding themselves on ships, but was higher for Asians (US\$3,900), who travelled a longer distance.

Two out of every five interviewed transit migrants entered Turkey without a passport or another valid travel document. More than twothirds of those who entered Turkey without a valid document were Iraqi citizens with ethnic identities of Kurd, Chaldean, or Turk. Almost all of the undocumented migrants who illegally arrived in Turkey had the help of traffickers and smugglers. Nearly one in every ten reported that they planned to enter their final destinations without a valid document, the majority hoping to have the help of traffickers and smugglers. Only $15 \%$ of the respondents were planning to use another country as a transit after leaving Turkey and before reaching their final destination. Major transit choices between Turkey and the destination not only included neighbouring countries such as Bulgaria, Cyprus, Greece, Italy, Romania, Spain, Iran, and Syria, but also far-away places such as Pakistan and the Philippines. The major target countries for final destination were Australia, Canada, the United States, and various European countries. Scandinavian countries, the Netherlands, the United Kingdom, Italy and Greece were among the more favourite destination points in Europe. Africans, the majority of whom were planning to work as sailors, constituted the group that had attempted to go to Greece and were still planning to go there. Almost $80 \%$ of the interviewed migrants said that they would have considered better living standards and job opportunities in choosing their final destination, while nearly $70 \%$ stated that political, social and cultural factors were important for their choices. Sixteen per cent were considering the countries with relatively loose visa requirements.

Only one-third of the respondents indicated that they would consider going to their homeland as an alternative. More than one-third were determined to migrate and said that they would not consider their homeland as an alternative under any circumstance. The remaining onethird could go back home if certain conditions were realised. A vast majority $(80 \%)$ stated that they would go back home if both economic and political conditions changed positively. Almost one in every five mentioned that they would 
consider returning home if they were paid for their travel expenses. This proportion was $70 \%$ for Africans.

Two-thirds of the sampled transit migrants answered 'yes' when asked whether they would have left their homeland if they had known beforehand all the problems they would have. This proportion was quite uniform acrosss national and ethnic groups. Ninety-three per cent of those who said 'yes' were determined to leave Turkey for another country, although $72 \%$ of them had not been successful on their first attempt and $20 \%$ were twice unsuccessful.

\section{Concluding remarks}

As I argue elsewhere (Içduygu and Keyman 1998), intense processes of globalisation are forcing us to rethink the state-centric approach to the question of international migration. The processes of globalisation have the potential to make the question of international migration complex, complicated and multi-dimensional, whose changing nature cannot be captured within the limits of the conventional approaches. For this reason, attention should be paid to exploring various ways in which the link between globalisation and politics of international migration is constructed both spatially and historically. In this article, I have attempted to do so by focusing on the case of transit migration in Turkey as one of the significant sites at which the effect of globalisation can be seen clearly.

In conclusion, it is possible to make two main observations concerning the dynamics and mechanisms of the recent transit migration flows in Turkey as they are articulated into the European IMRs.

First, the preceding discussion leaves very little room for doubt about the existence of substantial levels of increasing transit migration flows in Turkey in the 1980s and 1990s. Although direct evidence is lacking for the present situation, it is plausible to assume that a similar kind of mobility will also exist in the 2000s - but with some ups and downs. Some recent figures suggest that Turkey will continue to experience modest reductions in the transit migration flows but that the decline will be neither rapid nor uniform. The pace of change will be slower in the context of the failure of social, political, and economic improvements in the Middle East, Asia, and Africa, the persistence of migration networks between the potential migrants and their relatives and friends who already live abroad and at home, and the ongoing demand for human resources in the receiving countries. It is obvious that such reasons may not necessarily keep the migration flows high. Critical in this regard are the immigration and asylum policies and practices of the receiving countries in the developed regions (West and North) toward emigration and asylum flows coming from the developing regions (East and South).

Second, in an international environment where rigid restrictive policies put limits on immigration and asylum flows, differential migratory response to broad-based IMRs would result in an increasing trend in transit migration movements. Some clear tendencies in this direction have already been seen for the last two decades. For instance, many transit migrants have entered the peripheral regions surrounding Europe; transit migration in Turkey is one of these examples.

Although there are common features, each migratory movement between Europe and Turkey in the 1980s and 1990s is a particular case with unique aspects of its own. In short, IMRs remain diverse. They serve particular interests in the various key actors, i.e. migrants, receiving countries and sending countries, which reflect the various mechanisms and dynamics in the world migration market. There is, therefore, no single international migration regime between Europe and Turkey. There are a number of regimes that overlap and occur as the outcome of interactions among the migrants, their homelands and destinations. Accordingly, transit migration flows in Turkey have formed their own regime.

What is common to this migration regime might be summarised at three levels. At one level, it establishes a balance between the mobility of individual migrants and the needs of the international migration market. At a second level, it organises the relations between the sending countries and receiving countries, which compete as centre and periphery. At a third level, it distributes power between (sending, transiting, and receiving) countries. 
Research designed to evaluate those levels within a single study is clearly needed. Such a study will require a synthesis of data and theoretical framework that emerges from various research practices in the field of international migration. It is within this context that the study of IMRs and their association with the changing politics of international migration could serve as a paradigm for comprehensive elaboration of the ongoing international migratory flows.

\section{Notes}

1. See, for instance, IOM (1994a, 1994b, 1995).

2. See, for instance, IOM, UNHCR, and OSCE (1996).

3. Part of the discussion on the transit migration flows in Turkey here was previously reported by the author of this essay in IOM (1995).

4. For detailed information on the recent refugee flows into Turkey see Kirisci (1994). The discussion here benefited largely from Kirisci's study.
5. This section of the present essay is largely based on the following two studies: IOM (1995), and Içduygu (1996a).

\section{References}

Appleyard, R. 1995. 'New Trends in International Migration:

Numbers, Directions, and

Dynamics', paper presented at the Euroconference on Migration and Multiculturalism, London, August 30-September 2, 1995.

ApPleyARD, R. 1991. International Migration: Challenges for the Nineties, Geneva: International Organization for Migration.

GoKdere, A. 1994. "An Evaluation of Turkey's Recent Migration Flows and Stocks", Turkish Journal of Population Studies, 16: 29-56.

IÇDUYGU, A. 1996a. 'Transit Migrants and Turkey', Review of Social, Economic and Administrative Studies, 10: 1-2, 127-142.

IÇDUYGU, A. 1996b. 'Citizenship at the Crossroads: Immigration and the Nation-State', in E. Kofman and G. Youngs (eds.), Globalization, Theory and Practice. London: Pinter, 150-162.

IÇDUYGU, A. 1995. 'Refugee Pressure Versus Immigration Pressure in Europe: The Perspective From a Sending Country', paper presented at the European Population Conference, Milano, September 5-11.

IÇDUYGu, A. and Keyman, F. 1998. 'Globalization, Security, and Migration: the Case of Turkey', paper presented at the Conference on International Migration, Challenges for European Populations, Bari, June 25-27.

IOM (International Organization for Migration). 1995. Transit Migration in Turkey. Budapest: IOM

Migration Information Programme.

IOM (International Organization for Migration). 1994a. Transit Migration in Hungary. Budapest: IOM Migration Information Programme.

IOM (International Organization for Migration). 1994b. Transit Migration in Russian Federation. Budapest: IOM Migration Information Programme.

IOM, UNHCR, and OSCE (International Organization for Migration, United Nations High Commissioners for Refugees, and Office for Democratic Institutions and Human Rights). 1996. CIS
Conference. Geneva: UNHCR

Public Information Service.

JoLy, D. 1999. 'Some Structural Effects of Migration on Receiving and Sending Countries', Euromed Meeting Expert on Migration and Human Exchanges, The Hague, 1-2 March, 1999.

JoLY, D. 1998. 'Temporary Protection within the Framework of a New European Asylum Regime'. The International Journal of Human Rights, 2 (3): 49-76.

Joly, D. 1996. Haven or Hell? Asylum Policies and Refugees in Europe. Basingstoke: Macmillan.

KIRISCI, K. 1994. "Refugee Movements and Turkey in the Post Second World War Era". Istanbul: Bogazici University Research Papers, ISS/POLS 95-01.

Morokvasic, M. 1984. 'Trend Report, Migration in Europe, Introduction', Current Sociology, 32 (2): 17-40.

Portes, A. and BACH, R. L. 1995. Latin Journey. London: University of California Press.

Portes, A. and Borocz, J. 1985.

"Contemporary Immigration: 
Theoretical Perspectives on its Determinants and Modes of Incorporation", International Migration Review, 23 (3): 606-630.
ZFT (Zentrum für Turkeistudien).

1996. Immigration Country Turkey.

Essen: Zentrum für Turkeistudien

Publication. 